\title{
Telaah Makna Pendidikan Islam Dalam Ritual Adat Lebaran Tinggi Pada Komunitas Adat "Wetu Telu" Di Bayan Lombok Utara
}

\author{
Lalu Habiburrahman \\ Sekolah Tinggi Keguruan dan Ilmu Pendidikan (STKIP) HAMZAR
}

\begin{tabular}{l}
\hline \hline Article Info \\
\hline Article history: \\
Received 17 Desember 2021 \\
Publish 04 januari 2022 \\
\\
\hline Keywords: \\
Pendidikan Islam, \\
Lebaran Tinggi, \\
Wetu Telu \\
\end{tabular}

Corresponding Author:

Lalu Habiburrahman

Sekolah Tinggi Keguruan dan Ilmu Pendidikan A(STKIP) HAMZAR

Email: laluhabibbayan@gmail.com

\section{PENDAHULUAN.}

Ritual adat dalam Islam masih menjadi perbincangan yang hangat oleh semua kalangan, terutama dikalangan agamawan. Berbagai macam pemahaman antara budaya dan agama selalu dikaitkan dengan ritual yang ada di masyarakat, seperti halnya ritual adat lebaran tinggi pada masyarakat adat "WetuTelu" di Bayan. Agama adalah suatu yang menjadi kepercayaan manusia yang diyakini dalam hati dan disimbolkan dengan berbagai tindakan yang berhubungan langsung dengan sang pencipta. Setiap agama memiliki cara pandang dan peribadatan yang berbeda antara agama yang satu dengan agama yang lain. Demikian juga Agama Islam, yang tidak bisa terlepas dari ritual-ritual keagamaan yang menarik dan erat hubungannya dengan adat istiadat masyarakat setempat. Praktik ritual agama Islam pada tiap-tiap daerah memiliki cara peribadatan yang berbedabeda.

Masyarakat secara sosial terpilah menjadi berbagai konfigurasi sosial, seperti: etnisitas, aliran pemikiran, organisasi sosial dan strata sosial lainnya.Segi budaya juga terpilah menjadi beraneka ragam suku, tradisi dan adat istiadat. Sedangkan dari segi agama, ada beberapa macam agama yang ada seperti, Islam, Hindu, Buda, Kristen dan Konghucu. Suku sasak yang berada di daerah Pulau Lombok adalah masyarakat dengan jumlah penduduknya $97 \%$ beragama Islam. Seorang etnografis pernah mengatakan "menjadi Sasak berarti menjadi Muslim”. Pandangan Judith Ecklund tentang Suku Sasak Lombok, memang tidak 100\% benar. Keislaman masyarakat sasak, masih sarat dengan budaya ritual-ritual adat yang ada. Bayan misalnya, dengan segelintir pengecualian, praktik keislamannya masih sarat diwarnai oleh kebudayaan asli setempat, dalam 
konteks kepercayaan dan keyakinannya masih bersifat sinkritisme, yaitu animisme dan dinamisme. Keyakinan semacam itu bersifatmistisme, yaitu; pahamajaran yang serba mistis, sehingga hanya dikenal, diketahui atau dipahami oleh orang-orang tertentu, terutama penganutnya. Hal demikian, oleh para peneliti yang telah melakukan penelitian di daerah Bayan Lombok, sering kali dikaitkan dengan kepercayaan masyarakat adat Wetu Telu.

Masyarakat adat WetuTelu di Bayan Lombok, dikenal sebagai masyarakat yang kaya akan tradisi ritual adat istiadat, baik dalam kehidupan sosial maupun dalam beragama. Masyarakat Bayan yang sebagian besar beragama Islam, namun masih banyak menyimpan dan mempertahankan tradisi adat budaya lokal peninggalan leluhurnya. Karena, Islam tersebar di seluruh nusantara ini selalu berbauran dengan adat budaya lokal setempat, demikian juga di Bayan Lombok.

Sebagiain kelompok keislaman ortodoks beranggapan bahwa, tradisi ritual adat lebaran tinggi di Bayan merupakan perbuatan ('amaliah) yang sia-sia, bahkan sampai dikatakan sesat. Karena tidak adanya petujuk yang sesuai dengan Al-Qur'an dan As-Sunnah untuk dijadikan dasar terhadap praktek tradisi adat lokal tersebut. Akan tetapi sebaliknya, komunitas masyarakat adat Bayan memandang, bahwa pelaksanaan ritual adat pada komunitas adat "wetu telu" di Bayan tidak hanya sekedar acara seremonial biasa, karena terdapat akulturasi nilai-nilai agama dan budaya. Sehingga masyarakat adat menilai, ritual-ritual adat tersebut tidak bertentangan dengan ajaran Islam. Dalam konteks inilah proses pemaknaan berlangsung, karena dengan segala unsur yang ada merupakan simbol yang mencakup banyak makna, terutama makna terhadap nilai-nilai pendidikan Islam ada di dalamnya. Dengan demikian, peneliti menggunakan kajian interpretatif sebagai rumusan dalam proses penelitian ini.

Akulturasi budaya dan agama dalam ritual adat lebaran tinggi pada komunitas adat "wetu telu", merupakan keunikan dari corak keberagaman ditengah masyarakat. Terlebih, tradisi ritual adat sudah ada sejak dahulu sebelum Islam datang ke pulau Lombok. Karena, nilai-nilai tradisi adat istiadat yang sudah ada sebelum keislaman, masih melekat dalam kehidupan masyarakat. Dalam Islam juga dikenal dan mengakui istilah kaidah hukum adat. Hukum adat merupakan suatu kebiasaan yang dilakukan sekelompok orang secara berulang-ulang. Hal demikain menegaskan bahwa, Islam cukup kooperatif dengan penomena serta dinamika kebudayaan yang ada. Terlebih jika adat istiadat tersebut merupakan tradisi yang membawa kemaslahatan yang baik bagi masyarakat setempat.

Ritual adat lebaran tinggi sebagai salah satu praktik ritual keagamaan di masyarakat adat wetutelu dan cukup masyhur dikalangan masyarakat Bayan. Perhatian masyarakat adat Bayan cukup besar terhadap ritual adat keagamaan, karena ritual adat ini didasarkan pada suatu pandangan, bahwa ritual adat sebagai nilai kebersamaan dan silaturrahim.

Ritual-ritual adat menjadi karakteristik komunitas adat Wetu Telu di Bayan. Sehingga Erni Budiwanti memandang Wetu Telu, kurang lebihnya masuk dalam katagori agama tradisional. Islam, sejak awal kemunculannya menghadapi beberapa perbedaan nilai-nilai yang kontradiktif dengan tradisi lokal dan budaya yang ada, hal tersebut menyebabkan sebuah proses yang menghasilkan warna Islam lokal. Sementara berdasarkan historis, pembumian Islam di Lombok diperkirakan terjadi pada abad ke XVI M. Masyarakat adat Wetu Telu di Bayan dalam mengekspresikan penghormatannya kepada Tuhan Yang Maha Esa melalui ritual-ritual adat keagamaan, dengan membawa makanan-makanan, hasil panen, hewan ternak dan lain sebagainya, sebagai wujud syukur atas karunia dan segala kenikmatan-Nya yang telah di berikan, dan dipersemabahkan juga untuk arwah para leluhur atas apa yang menjadi peninggalannya.

Selanjutnya sebelum pelaksanaan ritual solat id, masing-masing kiai melakukan mandi bersih ke sungai dirangkai dengan wudu' kemudian membawa air secukupnya dengan menggunakan canting (gayung) dari batok kelepa, selama dalam perjalanan dari tempat mandi menuju masjid kuno, para kiai sangat dilarang untuk berkata-kata, karena akan membatalkan kesuciannya. Kemudian setelah sampai di masjid, masing-masing kiai melakukan solat Syukurlu, 
solat syukurlu dilakukan sebelum solat id dimulai. Ritual solat id dilakukan secara berjamaah, yang imami oleh Amaq Lokaq Kiai selaku tetua yang dituakan. Ktib sebagai pembaca naskah ngoatbah (khutbah) adalah seorang kiai adat yang ditunjuk secara langsung oleh Amaq Lokaq Kiai sebagai tetua dari kiai santri, atau kelayakan kiai adat sebagai Ktib merupakan hasil musyawarah para kiai adat pada malamnya. Ngaji Makam dilakukan secara bersama-sama sebagai bentuk do'a yang dipersembahkan kepada arwah para leluhur dan dipimpin oleh Amaq Lokaq Kiai. Prosesi jamuan makan bersama untuk para hadirin yang mengikuti ritual adat, makan bersama dilakukan setelah selesai berdo'a bersama dan atas izin dari Amaq Lokaq Kiai. Setelah selesai makan bersama sebagai prosesi akhir ritual, jika ada sisa makanan yang telah dimakan, maka diharuskan untuk dibawa pulang.

Ritual adat lebaran tinggi, tidak hanya semata-mata sebagai kegiatan seremonial adat biasa, namun lebih kepada penanaman nilai tradisi yang diisi dengan kegiatan yang bernuansa Islami. Tradisi ritual adat lebaran tinggi bukanlah hal yang sis-sia dilakukan, karena terdapat makna pendidikan Islam yang dapat dibiasakan dan dilestarikan oleh masyarakat setempat. Maka perlu adanya kajian yang mendalam atau menelaah makna pendidikan Islam yang terkandung didalam ritual adat lebaran tinggi.

Ritual adat, faham dan keyakinan tentang Wetu Telu seolah menjadi primadona permasalahan dikalangan masyarakat luas, sejak dahulu sampai sekarang masih menjadi bahan perbincangan yang hangat oleh sejumlah kalangan masyarakat, baik dari kalangan agamawan, akademisi, sejarawan dan yang lainnya. Peneliti dalam kesempatan ini membahas salah satu ritual adat keagamaan masyarakat adat Wetu Telu di Bayan. Adapun obyek yang menjadi kepokusan dalam penelitian ini adalah ritual adat keagamaan masyarakat adat Bayan dengan kajian"Telaah Makna Pendidikan Islam Dalam Ritual Adat Lebaran Tinggi pada Komunitas Adat "Wetu Telu" di Bayan Lombok Utara".

\section{HASIL DAN PEMBAHASAN}

\subsection{Sejarah Ritual Adat Lebaran Tinggi}

Islam datang di negeri ini menjadi sebuah rahmat, kedatangan Islam dan penyebarannya ke seluruh nusantara baik kepada golongan bangsawan dan rakyat umumnya dilakukan secara damai. Jika dalam penyebaran Islam terjadi peperangan antar kerajaan yang ada, hal itu bukan karena persoalan agama semata, namun karena dorongan politis untuk menguasai kerajaankerajaan disekitarnya. Sewaktu islam datang di pulau Lombok, saat itu masyarakat Lombok telah memiliki kebudayaan dan kepercayaan yang mengandung nilai keagamaan, namun dalam kepercayaan tersebut masih dalam bentuk animisme dan dinamisme. Hadirnya Islam tidak melunturkan nilai-nilai kepercayaan tersebut, maka terjadilah perpaduan unsur-unsur yang mengandung arti tujuan yang sama.

Menurut Raden Driawali sebagai tokoh adat masyarakat Desa Sukadana, ritual adat lebaran tinggi awalnya dilakukan secara serempak sebagaimana mestinya yang sesuai dengan waktu, tempat dan tanggal yang telah ditetapkan, namun pada saat itu kehadiran kerajaan Anak Agung Hindu Bali di Lombok memiliki pengaruh besar terhadap keberlangsungan penyebaran Islam di pulau Lombok. Tantangan berupa tekanan untuk mengikuti kepercayaan dan budaya hindu saat itu terus dan terus di dilakukan oleh kerajaan Anak Agung Bali, sehingga oleh masyarakat adat Bayan untuk mengelabui tekanan tersebut, demi mempertahankan akidah keislaman mereka, masyarakat adat mengkolaborisikan antara budaya hindu dengan agama Islam.

Persi lain datangnya dari Maq Kiai semokan, pendapatnya hampir mirip dengan raden driawali tadi, namun disini lebih terfokus pada waktu ritual adat lebaran tinggi. Mengapa ritual adat lebaran tinggi dilakukan pada hari ketiga, empat dan lima bulan syawwal? Karena sebelum kedatangan kerajaan Anak Agung hindu Bali ke pulau Lombok, agama Islam sudah 
sejak lama tersebar di pulau Lombok melalui jalur pelabuhan carik di Bayan. Hal demikian terbukti melalui berdiri kokohnya masjid-masjid kuno yang tersebar di antero pulau Lombok.

Lebih lanjut menurut Mak Kiai, sekitar Abad 17an merupakan awal kedatangan kerajaan Anak Agung Bali ke pulau Lombok, kedatangannya memperkeruh urusan agama dan politik raja-raja di Pulau Lombok. Penyebaran agama Islam misalnya menjadi sangat terhambat, karena oleh Anak Agung Bali tekanan demi tekanan terus dilakukan pada rakyat jelata, sehingga waktu itu guru-guru kami sebagai pengemban amanah agama Islam yang diamanahkan oleh guru-gurunya untuk penyebaran Islam menjadi terhambat. Sejak waktu itulah guru-guru kami sebagai pengemban amanah da'wah Islam, demi keberlangsungan da'wah Islam di Lombok, mereka mengelabui Kerajaan Anak Agung Bali dengan mengalihkan waktu-waktu ibadah dan perayaan hari-hari besar Islam pada waktu-waktu yang tidak sama sperti biasanya.

Ritual adat lebaran tinggi di Bayan merupakan bukti sejarah, bahwasanya masyarakat adat telah mengalami proses penerapan keyakinan, sehingga keyakinan tersebut berakulturasi dengan adat budaya setempat kemudian menjadi pegangan hidup bagi masyarakat adat Bayan. Tradisi ini telah berepolusi menjadi keyakinan dalam kebudayaan yang keutuhannya masih sangat terjaga, karena jika dirubah maka akan berakibat fatal (medam) bagi pelaku perubahannya. Tradisi ritual adat lebaran tinggi merupakan salah satu tindakan keagamaan masyarakat adat Bayan yang diyakini keberadaannya masih sangat sakral.

\subsection{Wetu Telu Dalam Persepektif}

Pemahaman tentang Wetu Telu di daerah Lombok sangat identik dengan daerah Bayan. Oleh para peneliti dengan komunitas adat setempat, Faham Wetu Telu seringkali menjadi buah bibir permasalahan mengenai serapan makna. Berbagai konsep pemaknaan tentang Wetu Telu, tinjauan terhadap masing-masing tokoh adat yang diwawancarai. Mereka menyatakan bahwa, Wetu Telu bukan agama dan tidak ada kaitannya dengan waktu, tetapi merupakan falsafah hidup masyarakat adat Bayan. Wetu Telu bukan agama, melainkan sebuah faham kepercayaan masyarakat adat Bayan yang terwujud dalam berbagai pelaksanaan ritual adat.

Wetu Telu tidak ada sangkut pautnya dengan agama atau tata cara peribadatan keagamaan sehari-hari, tapi Wetu Telu hanyalah sistem tata kelola tiga wilayah kekuasaan di alam jagad raya, yakni Wet (wilayah), Tu (Orang) dan Telu (tiga), tiga wilayah kekuasaan yang dimaksud adalah wilayah kekuasaan Tuhan, wilayah kekuasaan pemerintah dan wilayah kekuasaan masyarakat biasa.

Sekian banyak warna pemaknaan tentang Wetu Telu yang datang dari masing-masing tokoh adat yang berbeda, tapi itu semua merupakan satu kesatuan pengertian. Para tokoh adat Bayan, semua bersepakat bahwa Wetu Telu bukanlah sebuah ajaran agama agama, namun lebih pada filosofi tata cara dalam mengemban kehidupan.

\subsection{Prosesi Ritual Adat Lebaran Tinggi}

Prosesi budaya ritual adat lebaran tinggi di Bayan merupakan salah satu dari sekian banyak ritual adat keagamaan yang hidup dan berkembang di daerah Bayan Lombok Utara. Ritual adat lebaran tinggi masih tetap mendapat tempat yang baik dalam kehidupan masyarakat, terutama dikalangan masyarakat adat Bayan. Animo masyarakat adat Bayan pada perayaannya terlihat dari antusias dan banyaknya pengunjung dari semua elemen masyarakat menjadikannya semarak kemeriahan dalam perayaannya. Kawan-kawan kalangan mediapun tidak pernah ketinggalan, mereka berdatangan dari alamat yang berbeda-beda hanya untuk menyaksikan dan meliput upacara ritual adat diselenggarakan.

Ritual adat lebaran tinggi adalah bagian dari tradisi kebiasaan yang dilakukan oleh sekelompok masyarakat adat Bayan yang menjadi pola keagamaan dalam mengekspresikan peribadatannya. Penyelenggaraan ritual dapat ditandai dengan adanya berbagai macam unsur, komponen, alat-alat dalam upacara serta orang-orang yang menjalankan upacara. Imam 
Suprayogo, mendefinisikan sebuah ritual dengan serangkaian kata, tindakan pemeluk agama dengan menggunakan benda-benda, peralatan dan perlengkapan tertentu, ditempat tertentu dan memakai pakaian tertentu pula. Ritual adat Lebaran Tinggi di Bayan, dalam penyelenggaraannya banyak menggunakan perlengkapan berupa makan-makanan, bendabenda yang harus dipersiapkan dan dipakai sejak awal sampai akhir ritual.

Komponen penting dalam sistem ritual adalah ritus dan upacara. Ritus dan upacara religi biasanya berlangsung berulang-ulang, baik setiap hari, setiap musim atau kadang-kadang tidak terikat dengan waktu dan musim, tergantung dari sisi acaranya. Sistem ritus dan upacara dalam ritual, terwujud sebagai simbol pada aktifitas dan tindakan manusia dalam melaksanakan hubungan terhadap Tuhan Yang Maha Kuasa, arwah para leluhur dan makhluk halus lainnya.

Ritus dan upacara religi biasanya terdiri dari beberapa kombinasi yang merangkaikan satu, dua atau beberapa tindakan, seperti: berdo'a, bersujud, bersaji, berkorban, makan bersama, bernyanyi dan menari, berseni drama suci, berpuasa, intoxikasi, bertapa dan bersemedi. Rangkaian kombinasi tersebut, pada ritual adat lebaran tinggi di Bayan dapat terpenuhi keculai bernyanyi dan menari. Kesemua rangakian prosesi adat lebaran tinggi, memiliki makna-makna pendidikan Islam yang tertuang di dalamnya.

\subsection{Simbol-Simbol dan Unsur-Unsur Ritual}

\section{a. Sinbol-Simbol Ritual}

Kehidupan manusia penuh diwarnai dengan simbol-simbol, sejarah manusia membuktikan bahwa ditemukannya tindakan-tindakan manusia yang berhubungan dengan agama, politik, ekonomi dan lain sebagainya didasarkan pada simbol-simbol yang ada. Penggunaan simbol merupakan salah satu ciri yang menonjol dalam pelaksanaan ritual adat lebaran tinggi. Karena, barangkali simbol menyimpan daya magis lewat kekuatan abstraknya untuk membentuk dunia melalui pancaran makna yang terkandung di dalamnya. Kekuatan simbol mampu menggiring siapapun untuk mempercayai, mengakui, melestarikan atau mengubah persepsi hingga tingkah laku orang dalam bersentuhan dengan realitas. Daya magis simbol tidak hanya terletak pada kemampuannya mempersentasikan kenyataan, tetapi realitas juga direfresentasikan lewat penggunaan logika symbol.

Sekian banyak simbol yang ada pada ritual adat lebaran tinggi, secara kongkrit berbentuk simbol religi dan non-religi. Simbol-simbol tersebut dipentaskan dalam ritus-ritus yang dikaitkan dengan mitos-mitos, menyebabkan getaran terhadap rasa-rasa aneh yang dirasakan. Kekuatan khas simbol-simbol tersebut berasal dari kemampuan mereka yang dikira ada untuk mengidentifikasi fakta dengan nilai pada taraf yang paling fundamental, untuk memberikan sesuatu yang bagaimanpun juga bersifat faktual murni, suatu muatan normatif yang konperhensif. Simbol-simbol yang sakral menghubungkan pada sebuah ontologi, kosmologi, estetika dan moralitas.

Bahasa simbol mempunyai peran penting dalam menjalani kehidupan sehari-hari dan terdapat juga diberbagai agama yang ada. Seperti yang diungkapkan Ernest Cassier, bahwa manusia dalam segala tingkah lakunya banyak dipengaruhi dengan simbol-simbol sehingga manusia disebut sebagai "Animal Symbolicum" atau hewan yang bersimbol. Penggunaan simbol dalam kehidupan masyarakat adat Bayan sangat nampak jelas terlebih dalam upacara-upacara adat, hal demikian merupakan warisan turun temurun dari generasi ke generasi yang sarat dengan makna.

Simbol merupakan alat atau sarana untuk dapat mengenal akan yang kudus dan yang transenden. Manusia tidak mampu mendekati yang kudus secara langsung, sebab yang kudus itu transenden, sedangkan manusia adalah makhluk temporal yang terikat di dunianya. Ketergantungan individu pada kekuatan goib ditemukan dari zaman purba sampai pada zaman moderen. Dengan demikian, bahasa simbol memang sulit dipisahkan dari kehidupan manusia. Karena, kehidupan beragama atau keyakinan relgius adalah kenyataan 
hidup manusia sepanjang sejarah, adanya simbol merupakan sarana untuk mengenal yang kudus dan yang transenden. Pendek kata, dalam tradisi ritual perlu dipelajari juga hal-ihwal yang berkaitan dengan metaperformative dan metafactitive, sehingga akan terungkap makna-makna dibalik simbol mistik ritual.

b. Unsur-Unsur Ritual

Upacara ritual adat lebaran tinggi merupakan serangakaian tindakan atau perbuatan yang terikat pada aturan tertentu berdasarkan adat istiadat, agama dan kepercayaan. Upacara-upacara ritual adat yang ada di Bayan merupakan warisan leluhur selain dari mitologi dan legnda-legenda sejarah. Ritual adat lebaran tinggi pada umumnya memiliki nilai-nilai sakral oleh masyarakat pendukung kebudayaan tersebut, penyelenggaraan ritual adat itu sangat penting bagi pembinaan sosial budaya masyarakat setempat. Norma-norma dan nilai-nilai budaya yang ada secara simbolis ditampilkan dalam bentuk upacara yang dilakukan oleh seluruh masyarakat adat Bayan.

Pelaksanaan ritual adat lebaran tinggi termasuk dalam golongan ritual adat yang tidak mempunyai akibat hukum, hanya saja apabila tidak dilakukan oleh masyarakat adat setempat maka timbul rasa kekhawatiran akan terjadi sesuatu yang menimpa pada dirinya. Dalam ritual adat lebaran tinggi di Bayan terdapat beberapa unsur-unsur yang mejadi keharusan dalam pelaksanaannya, diantaranya

1) Lekoq dan buaq (daun sirih dan buah pinang)

Lekoq dan buaq menjadi bagain yang tidak bisa terlepaskan oleh sebagian besar masyarakat adat, baik dari kalangan muda sampai kalangan tua dan sepuh. Lekok dan buaq merupakan pasangan sejoli yang tidak dapat dipisahkan, karena jika salah satu diantaranya tidak ada dalam penyajiannya maka tidak dapat disebut sebagai pamaq. Lekok dan buaq sudah dikenal oleh masyarakat adat Bayan sejak zaman alif (zaman yang tidak diketahui awal mulanya).

Lekoq dan buaq belum dapat disajikan sebagai alat dalam ritual adat lebaran tinggi sebelum dipersatukan menjadi satu kesatuan yang utuh, lekoq dan buaq disatukan dengan cara dikunyah oleh masyarakat adat setempat sehingga menjadi pamaq. Biasanya lekoq dan buaq dikunyah maka akan berubah warna menjadi warna merah kecoklatan, setelah selesai dikunyah, ampas yang ada didalam mulut si pengunyah akan dikeluarkan sehingga disebut sabagai pamaq. Pamaq sebagai sajian utama dalam ritual ngaji kubur menjadi hal yang sangat urgen dan penting, kehadiran pamaq dalam ritual ngaji kubur adalah sajian wajib karena setelah selesai acara ritual ngaji kubur, semua masyarakat adat diwajibkan untuk besembeq.

2) Mantra, Sesajian dan Kemenyan

Dalam prosesi ritual adat lebaran tinggi, mantra, sesajian dan kemenyan juga menjadi bagian terpenting dalam perayaan ritual adat sebagai ritusnya. Sajian makanan dan benda-benda dianggapnya menjadi sebuah perbuatan yang biasa dilakukan sebagai bagian dari sedekah kepada arwah nenek moyangnya, sehingga mereka beranggapan bahwa suatu aktifitas berupa mantra, sesajian dan kemenyan secara otomatis seolaholah menghasilkan tujuan yang dimaksud.

Biasanya, unsur terpenting dalam pelaksanaan beberapa ritual yang ada adalah mantra $\left(d o^{\prime} a\right)$ yang diiringi dengan gerak-gerik dan sikap tubuh. Sikap tubuh dalam berdo'a menunjukkan penghormatan dan kerendahan diri terhadap Tuhan yang Maha Esa dan arwah para leluhur. Sedangkan kemenyan disajiakan untuk harum-haruman menjadikan ke-khusyuan dalam bermantra atau berdo'a

3) Aktor-aktor Dalam Ritual

Sebagai aktor utama dalam pelaksanaan ritual adat lebaran tinggi adalah mak kiai, mak kiai santri, pembekel, mangku adat dan mangku gumi. Aktor-aktor yang 
terlibat dalam pelaksanaan upacara ritual adat tersebut adalah mereka yang bertindak sebagai pemimpin jalannya upacara ritual adat dan beberapa orang yang faham pada ritual tersebut. Berjalannya acara ritual adat lebaran tinggi didukung juga oleh semua kalangan masyarakat adat yang kebanyakan diantara mereka memahami arti penting peritualan

4) Tempat-tempat Ritual

Tempat-tempat yang diggunakan menjadi tempat keberlangsungan acara ritual adat lebaran tinggi adalah tempat yang bersifat sakral dan suci. Tidak semua orang dapat mengunjungi tempat yang sakral tersebut, karena pada dasarnya tempat tersebut hanya digunakan oleh orang-orang yang berkepentingan saja, dalam hal ini adalah pelaku yang terlibat dalam pelaksanaan ritual adat lebaran tinggi adalah, mak kiai, mak kiai santri, pembekel, mangku adat dan mangku gumi. Mereka semua menjadi pemeran utama dalam pelaksanaan ritual adat lebaran tinggi di Bayan.

Adapun tempat-tempat yang digunakan dan menjadi serangkaian tempat acar ritual adat, diantaranya; masjid kuno semokan, kampu dan kuburan nenek moyangnya

\subsection{Internalisasi Makna Ritual Adat Lebaran Tinggi Sebagai Pendidikan Islam}

Sebagai agama, Islam bukan hanya sekumpulan doktrin Ilahi dan kenabian yang transenden, tatapi juga terwujud dalam realitas sosial, Islam di dunia dibedakan dalam tiga bentuk sasaran studi: pertama, Islam sebagai doktrin (Islamic). Kedua, ketika doktrin itu masuk dan berproses dalam sebuah masyarakat kultural (islamicate) dan mewujudkan diri dalam masyarakat kultural dan kesejahteraan tertentu. Ketiga, islam menjadi dunia islam yang politis dalam lembaga kenegaraan (islamidom). Ritual adat lebaran tinggi dalam proses akomodasi kultural dapat dilihat kemampuan Islam beradaptasi dengan tradisi dan adat lokal serta kemampuan untuk mempertahankan nilai-nilai pokok keislaman. Proses akomodasi kultural ummat Islam memperlihatkan interaksi yang cukup intens antara agama yang bersifat universal dengan nilai, norma serta praktik sosial yang bersifat local.

Bassam Tibi menyatakan bahwa islam yang telah diturunkan di tengah-tengah bangsa Arab telah diadopsi oleh masyarakat non-Arab dengan kultur yang berbeda, sehingga dalam memahami ajaran Islam masing-masing memiliki perbedaan. Perbedaan itu memunculkan banyak corak islam, ada islam arab, Islam indonesia, Islam Afrika dan lain sebaginya. Masingmasing varian mempersentasikan dimensi budayanya sesuai dengan interpretasi mereka terhadap ajaran Islam. Karena itu, agama oleh para ilmuan muslim yang berbasis ilmu antropologi tidak jarang dianggap sebagi bagian dari sistem budaya (sisten kognisi), selain agama juga dianggap sebagi sumber nilai (sistem nilai) yang tetap harus dipertahankan aspek otentisitasnya. Dalam perspektif ini, disatu sisi agama difahami sebagai hasil dari tindakan manusia baik berupa budaya maupun peradaban, disisi lain agama tampil sebagai sumber nilai yang mengarahkan bagaimana manusia seharusnya berprilaku.

Kreasi paling monumental berwujud dalam berbagai macam ritual dan institusi keagamaannya yang sangat dipengaruhi oleh kekuatan-kekuatan budaya lokal, sejauh mana dapat difahami dalam membangun penafsiran, pemahaman serta kreativitas atas nama Islam. Upacara ritual adat lebaran tinggi sebagai bentuk realitas tertuang dalam internalisasi lokalitas dalam ranah studi Islam yang terbingkai dalam aspek ritual. Internalisasi nilai-nilai ritual adat dalam Pendidikan Islam sebenarnya memiliki bobot yang sama dan nilai-nilai tersebut yang sama pentingnya, sebab semua nilai itu berasal dari Allah SWT, nilai yang tertinggi. Artinya, untuk menetapkan hirarki nilai dalam ritual adat masyarakat perlu menetukan nilai dari masyarakat setempat.

Islam sebagai agama memberikan tekanan yang besar terhadap aktifitas ritual adat lebaran tinggi dalam berbagai acara dan aktifitasnya, Islam yang bercampur dengan budaya lokal adalah gejala normal dari dinamika ummat islam di Bayan. Pergumulan dan interaksi 
ummat islam dengan beraneka ragam tadisi dan budaya akan mengkondisikan munculnya karakter yang lebih pada akomodatif. Sebaliknya, semakin minim interaksi ummat Islam terhadap kebudayaan lokal, maka akan semakin miskin apresiasinya tergadap budaya lokal. Oleh karenanya, dengan menganalisis permasalahan ritual adat lebaran tinggi, maka dapatlah diketahui berbagai macam acara yang penuh dengan simbol-simbol keagamaan dan dapat diinternalisasi sebagai pendidikan islam. Simbol-simbol keagamaan tersebut merupakan upaya untuk memberikan penjelasan konprehensif dan konstruktif dari makna-makna yang sebanarnya.

\section{KESIMPULAN.}

Budaya ritual adat lebaran tinggi bersendikan agama yang disebut sebagai adat game. Artinya, kerap kali masyarakat adat melaksanakan kegiatan ritual dalam setiap kegiatannya, baik ritual kemanusiaan maupun kegiatan ritual yang hubungannya dengan Tuhan, prosesi ritual tersebut selalu diakhiri dengan acara keagamaan. Hubungan kekerabatan yang ada pada masyarakat adat Bayan terjadi antara manusia dengan manusia lainnya, hubungan antara manusia dengan Tuhan dan manusia dengan alam sekitarnya. Keharmonisan hubungan tersebut terefleksi pada ungkapan "solah tegaweq soleh tedait, lenge tegaweq lenge tedait". Artinya, kebaikan tingkah laku dan tutur kata seseorang dalam menjalani kehidupan di dunia maka akan berakibat baik pula, bahkan akan selalu dikenang walau sudah tiada. Sebaliknya, jika tingkah laku seseorang tidak baik dalam mengarungi kehidupannya secara sosisal masyarakat, sosial lingkungan dan hubungannya dengan Tuhan, maka akan berakibat tidak baik pula hasil yang diperoleh bagi dirinya.

Ritual adat lebaran tinggi mengajarkan arti penting berbagi antar sesama, ritual serah fitrah menjadi contoh kongkrit dalam berbagi antar sesama. Artinya semangat kebersamaan pada pelaksanaan ritual dengan membawa-bawaan yang sesuai dengan kebutuhan masyarakat setempat, seperti; membawa beras, ayam, kambing dan segala macam makanan sebagai kebutuhan pokok masyarakat pada saat pelaksanaan ritual tersebut. Sehingga rasa persaudaraan yang erat tertanam dalam diri masing-masing anggota masyarakat adat menjadikan ke-solidan dalam mempertahankan ritual adat. Selama dalam penelitian, baik secara observasi maupun tindakan, peneliti dapat menginterpretatif beberapa makna pendidikan yang terkandung dalam ritual adat lebaran tinggi di Bayan, yang terbagi menjadi lima kategori, diantaranya:

Pertama, makna pendidikan islam yang hubungannya dengan sang kholik (pencipta). Bagi masyarakat adat Bayan, ritual yang dilakukannya merupakan bentuk ketaatan mereka dalam mempersembahkan rasa syukur terhadap nikmat yang telah diberikan oleh sang Kholik kepada diri mereka. Nampak jelas bahwa ketatan dalam menjalankan perintah yang dilakukan oleh masyarakat adat dalam rangkaian acara ritual menjadi bukti peninggalan leluhur, seperti sembahyang, berdo'a. Jadi masyarakat adat Bayan dalam pelaksanaan ritualnya sudah barang tentu menjadi proses hubungan dengan sang Kholik (Tuhan) sangat erat, hal itu terungkap dalam ajaran dasar Islam untuk selalu menjaga hubungan dengan Allah SWT (حبل من الله (حب).

Kedua, makna pendidikan islam hubungannya dengan sesama manusia. Ritual adat lebaran tinggi dapat memperat tali silaturrahim dengan sesama, tentunya serah fitrah, ngaji kubur dan makan bersama menjadi bukti kongkrit dari (حبل من الناس).

Ketiga, makna pendidikan islam hubungannya dengan sesama makluk. Interaksi yang dibangun dalam ritual adat lebaran tinggi adalah akhlak yang menjalin hubungan antar sesama makhluk, baik yang kongkrit ataupun yang abstrak. Manusia diciptakan oleh Allah SWT dengan sangat sempurna, kesempurnaanya mejadikan manusia sebagai khalifah dimuka bumi ini. Hubungan baik antar sesama makhluk telah diatur sejak lama dalam ajaran Islam, namun banyak diantara manusia tidak mampu menjalankan amanah tersebut. Bayan, dengan kekuatan adat dan mitos yang berkembang, menjadikan proses interaksi antar sesama makhluk dan alam sekitar dapat terjaga dengan sangat baik. 
Keempat, makna pendidikan islam hubungannya dengan fikih lingkungan atau alam semesta. Mitologi yang kembangkan dalam ritul adat lebaran tinggi mampu menjadikan alam disektarnya tetap terjaga kelestariannya. Islam mengajarkan hidup selaras dengan alam, banyak ayat Al-Quran maupun hadis yang bercerita tentang lingkungan hidup dan kitab fikih yang menjadi penjabaran keduanya, masalah lingkungan ini masuk dalam bidang jinayat (hukum). Artinya, kalau sampai ada seseorang menggunduli hutan dan merusak hutan, itu harus diberlakukan sanksi yang tegas, harus dicegah dan harus dihukum. Hal demikian sesuai dengan mitologi yang dikembangkan dalam hukum adat Bayan agar supaya kelestarian hutan tetap terjaga. Dan sangat jelas ayat yang mengatakan

" (jangan merusak alam ini, merusak bumi ini sesudah ditata sedemikian baik).

Kelima, makna pendidikan islam hubungannya dengan arwah para leluhur. Penghormatan arwah leluhur dalam budaya ritual adat lebaran tinggi adalah kebiasaan yang dilakukan anggota keluarga yang masih hidup untuk mendo'akan anggota keluarga yang sudah meninggal dan membuat mereka berbahagia di akhirat. Praktik tersebut merupakan upaya untuk tetap menunjukkan kebaktian kepada mereka yang telah meninggal, dan juga memperkokoh persatuan dalam keluarga yang segaris keturunan. Menunjukkan rasa bakti kepada leluhur merupakan sebuah ideologi yang berakar mendalam pada masyarakat adat Bayan.

\section{DAFTAR PUSTAKA}

2014)

, Sejarah Teori Antropologi I, (Jakarta: UI Press, 1987)

Abu Nashim Muchtar, Antara Tradisi dan Sendi-Sendi Tauhid, (Yogyakarta: Arta Media, 2003)

Agus Bustanuddin, Agama Dalam Kehidupan Manusia: Pengantar Antropoligi Agama, (Jakarta: Grafindo Persada, 2006)

Ajid Tohir dan Ading Kusdiana, Islam di ASIA Selatan; Melacak Perkembangan Sosial, Politik Ummat Islam Di India, Pakistan Dan Bangladesh, (Bandung: Humaniora,2006)

Badri Yatim, Sejarah Peradaban Islam: Dirasah Islamiyah II, (Jakrta: PT. Raja Grafindo Persada, 2008)

Bassam Tibi, The Crisis of Moderen Islam, (Salt Lake City: University of Utah press, 1988)

Clifford Gertz, Kebudayaan dan Agama, terj. Francisco Budi Hardiman, (Yogyakarta: Kanisius, 1992)

Depdikbud, Monografi Daerah Nusa Tenggara Barat, (Mataram: Depdikbud, 1975)

Ernest Cassier, Manusia dan Kebudayaan, terj. Alois A. Nugroho (Jakarta: Gramedia, 1990)

Erni Budiwanti, Islam Sasak; Wetu Telu Versus Waktu Lima, Cet. II, (Yogyakarta: Lkis Printing Cemerlang, 2013)

Fauzi Fahri, Penyingkapan Kuasa Simbol, Aproriasi Reflektif Pemikiran Piere Bourdieu, (Yogyakarta: Juxtapos, 2007)

H. Bahrudin, Bahri, Study Sejarah dan Budaya Lombok, (Lombok Timur : Pusankanda, https://id.wikipedia.org/wiki/Mistisisme. 2 Juni 2021

Imam Suprayogo, Metodologi Penelitian Sosial Agama, (Bandung: Remaja Rosda karya, 2001)

Judith Ecklund, Tradition or Non Tradition: Adat, Islam, and Local Control on Lombok, (New York: Cornell Univercity Press, 1981)

Koenjaraningrat, Beberapa Pokok Antropolgi Sosial, (Jakarta: Dian Rakyat, 1985)

P.S. Hari Susanto, Mitos Menurut Mircea Eliade, (Yogyakarta: Kanisius, 1987)

Sulaiman, Menguak Makna Kearifan Lokal Pada Masyarakat Multikultural, (Semarang: Robar Bersama, 2011)

Uka Tjandrasasmita, Sejarah Nasional Indonesia III, (jakarta: PN. Balai Pustaka, 1984) 